\title{
ORBITAL AND LABORATORY SPECTRAL DATA TO OPTIMIZE SOIL ANALYSIS
}

\author{
Peterson Ricardo Fiorio ${ }^{1 *}$; José Alexandre M. Demattê \\ ${ }^{1}$ USP/ESALQ - Depto. de Engenharia Rural, C.P. 09 - 13418-900 - Piracicaba, SP - Brasil. \\ ${ }^{2}$ USP/ESALQ - Depto. de Solos e Nutrição de Plantas, C.P. 09 - 13418-900 - Piracicaba, SP - Brasil. \\ *Corresponding author <fiorio@esalq.usp.br>
}

\begin{abstract}
Traditional soil analyses are time-consuming with high cost and environmental risks, thus the use of new technologies such as remote sensing have to be estimulated. The purpose of this work was to quantify soil attributes by laboratory and orbital sensors as a non-destructive and a nonpollutant method. The study area was in the region of Barra Bonita, state of São Paulo, Brazil, in a 473 ha bare soil area. A sampling grid was established $(100 \times 100 \mathrm{~m})$, with a total of 474 locations and a total of 948 soil samples. Each location was georeferenced and soil samples were collected for analysis. Reflectance data for each soil sample was measured with a laboratory sensor (450 to 2,500 nm). For the same locations, reflectance data was obtained from a TM-Landsat-5 image. Multiple linear regression equations were developed for $50 \%$ of the samples. Two models were developed: one for spectroradiometric laboratory data and the second for TM-Landsat-5 orbital data. The remaining 50\% of the samples were used to validate the models. The test compared the attribute content quantified by the spectral models and that determined in the laboratory (conventional methods). The highest coefficients of determination for the laboratory data were for clay content $\left(\mathrm{R}^{2}=0.86\right)$ and sand $\left(\mathrm{R}^{2}=0.82\right)$ and for the orbital data $\left(\mathrm{R}^{2}=0.61\right.$ and 0.63 , respectively). By using the present methodology, it was possible to estimate $\mathrm{CEC}\left(\mathrm{R}^{2}=0.64\right)$ by the laboratory sensor. Laboratory and orbital sensors can optimize time, costs and environment pollutants when associated with traditional soil analysis. Key words: remote sensing; soil attributes; soil reflectance
\end{abstract}

\section{DADOS ESPECTRAIS ORBITAIS E DE LABORATÓRIO NA OTIMIZAÇÃO DA ANÁLISE DO SOLO}

RESUMO: Analises de solos tradicionais consomem tempo com alto custo e riscos ambientais. Dessa forma, o uso de novas tecnologias como o sensoriamento remoto tem sido estimulado. $\mathrm{O}$ objetivo do trabalho foi quantificar atributos dos solos por um método não destrutivo e não poluente utilizando sensor de laboratório e orbital. A área de estudo localiza-se na região de Barra Bonita, Brasil, com 473 ha com solo exposto. Foi estabelecida uma malha de amostragem $(100 \mathrm{~m} \times 100 \mathrm{~m})$ com 474 pontos de amostragem e um total de 948 amostras de solos. Os pontos de amostragem foram georreferenciados, e amostras de solos coletadas e enviadas para análises. Os dados de Reflectância foram obtidos para cada amostra de solo com o sensor em laboratório (450 a $2500 \mathrm{~nm}$ ). Nos mesmos locais de amostragem de solos, foram obtidos dados de reflectância de imagens orbitais TM-Landsat-5. Equações lineares de regressão múltiplas foram desenvolvidas com 50\% das amostras. Dois modelos foram desenvolvidos: o primeiro com dados de espectroradiometria de laboratório e o segundo para os dados orbitais da imagem TM Landsat-5. O restante das amostras, 50\% foram utilizadas para validar o modelo. O teste comparou os valores dos atributos quantificados pelos modelos espectrais e os determinados em laboratório (método convencional). Os maiores coeficientes de determinação para os resultados de laboratório foram para argila $\left(\mathrm{R}^{2}=0,86\right)$ e areia $\left(\mathrm{R}^{2}=0,82\right)$ e para os dados orbitais $\left(\mathrm{R}^{2} 0,61\right.$ e 0,63 , respectivamente). Também foi possível com o presente método estimar $\mathrm{CTC}\left(\mathrm{R}^{2}=0,64\right)$ para o sensor de laboratório, podendo otimizar tempo, custos e poluições ambientais associadas com as análises de solos tradicionais.

Palavras-chave: sensoriamento remoto, atributos do solo, reflectância do solo

\section{INTRODUCTION}

Soil analysis is a widely employed basic instrument for the diagnosis of soil fertility (Raij et al., 1987). Commonly used laboratory methods are analytical and require a lot of time in order to reach an acceptable degree of reliability. The techniques consist of soil sample collection in the field, then subjecting them to a series of processes in order to determine their chemical and physical composition. In Brazil, these meth- 
ods include those presented by Camargo et al. (1987) and Raij et al. (1987). The results of soil analyses are used for a series of activities, including soil classification and recommendations for the application of fertilizers, both important for soil management. Soil sample collection for the determination of fertility can be carried out by traditional methods, with the general rule being that one soil sample consists of 20 subsamples in an area not larger then 20 ha (Raij et al., 1996), or according to the practices of modern precision agriculture which would suggest a sampling grid of 20 to $30 \mathrm{~m}$ for experimental areas.

Due to the number of samples, the costs of soil analysis are higher for precison agriculture than for traditional agriculture (Demattê et al., 2000). Therefore, it is essential to find a more efficient approach to the practice of sampling sites. The question is: which criteria should be established for the determination of a sampling grid in precision agriculture without knowledge about the homogeneity and heterogeneity of the soils in a given area? In relation to this, Demattê (2001) emphasized the importance of the use of new technologies such as remote sensing. In fact, remote sensing and statistical analysis were the most efficient and least costly techniques for soil evaluation (Odeh \& MacBratney, 2000). Besides laboratory spectral data, this information can be obtained by satellites. The use of orbital data is justified depending on the objectives of the user, i.e. when evaluating areas from distance. Thus, the comparison between laboratory and orbital data is important to verify their efficiency. Several authors have also employed the results of correlation analyses between soil attributes and spectral reflectance as the basis for soil quantification (Galvão et al., 1997; Demattê \& Garcia, 1999). Similarly, prediction models of soil characteristics have shown a high potential (Morra et al., 1991; Ben-Dor et al., 1997).

Since reflected energy has a strong physical relation to several soil attributes (e.g. clay, sand), we expect that spectral information present a model that make the quantification of these attributes possible. This has led to the present study, where the objective was to evaluate soil attribute quantification from multiple linear regression analysis using spectral reflectance measured at laboratory and orbital levels of data acquisition.

\section{MATERIAL AND METHODS}

\section{Characterization of the study area}

The area is located in Brazil, the Barra Bonita region, southeast of the São Paulo State, delimited by the geographical coordinates $22^{\circ} 26^{\prime}-22^{\circ} 23^{\prime} \mathrm{S}$ and $48^{\circ} 31^{\prime}-48^{\circ} 27^{\prime} \mathrm{W}$, and comprising $473 \mathrm{ha}$, used for sugarcane cultivation at altitudes ranging from 520 to $710 \mathrm{~m}$ asl. The climate of the region was classified according to the Köppen system as a Cwa type, as a mesothermic climate (Sentelhas et al., 1998).

The lithology is mainly represented by the Serra Geral formation, which is characterized by a set of basaltic rocks interlaced with sandstone, showing the same characteristics as the Botucatu formation. In addition, the Itaqueri formation of the Bauru group characterized by sandstone with clayey cement, shales and conglomerates was observed, with a predominance of sandstone (IPT, 1981).

\section{Soil sampling grid}

A regular grid measuring $100 \times 100 \mathrm{~m}$ was established, and the vertices were flagged, georeferenced and sampled at depths of $0-20$ and $80-100 \mathrm{~cm}$, called layers A and B, with a total of 948 soil samples. Soil color was determined in humid samples using a Minolta CR 300 apparatus equipped with a Munsell color chip (Post et al., 1994; Campos et al., 2003). The samples were submitted to chemical (Raij et al., 1987) and granulometric analysis, as well as sulfuric acid digestion (Camargo et al., 1987), and seven soil profiles (Lemos \& Santos, 1996) were described, forming the basis of a soil classification (Embrapa, 1999). According to the Embrapa (in parenthesis according to USDA, 1998), these soils were classified as Cambissolos Háplicos (Lithic Distrochept), Latossolos Vermelho-Amarelos (Typic Hapludox), Latossolos Vermelhos (Rhodic Eutrudox), Argissolos Vermelhos (Typic Hapludult), Neossolos Quartzarênicos (Typic Quatzipsamment).

\section{Acquisition of laboratory spectral data}

Laboratory spectral data were obtained with the Infra-Red Intelligent Spectroradiometer (IRIS) sensor (Geophysical \& Environmental Research, 1996), covering the spectral range from 450 to $2500 \mathrm{~nm}$, with a $2 \mathrm{~nm}$ spectral resolution between 450 and $1000 \mathrm{~nm}$ and $4 \mathrm{~nm}$ between 1000 and $2500 \mathrm{~nm}$. Soil samples from layer A $(0-20 \mathrm{~cm})$ and B $(80-100 \mathrm{~cm})$ were dried in an oven at $45^{\circ} \mathrm{C}$ for $24 \mathrm{~h}$, ground and sifted through a 2-mm sieve for homogenization for the effects of moisture and roughness (Henderson et al., 1992). The samples were then placed on petri dishes and illuminated with a $650-\mathrm{W}$ halogen lamp. The electric current feeding the lamp was stabilized with a $1 \%$ power source. A white plate was used as standard (Labsphere, 1996). The lamp was positioned $61 \mathrm{~cm}$ from the soil samples and the distance between the sample and the sensor was $27 \mathrm{~cm}$, with the lamp inclined $20^{\circ}$ from nadir (Baumgardner et al., 1985). The relationship between the energy reflected by the sample 
and the energy reflected by the reference plate generated a bidirectional reflectance factor. Three readings were obtained for each sample and the mean spectral curve was used for analysis.

\section{Acquisition of orbital spectral data}

Spectral data was acquired using bands 1, 2, $3,4,5$ and 7 of a TM-Landsat-5 scene. The image was cut using the IMPIMA program (INPE, 1999) after definition of the area. Each pixel in the satellite image corresponds to a grey level value (Crósta, 1992). The grey level values obtained from TM-Landsat sensor scenes should be properly adjusted to atmospheric effects and digital numbers should then be converted into true reflectance values (Ben-Dor, 2002). For this purpose, the $5 \mathrm{~S}$ model (Satellite Signal Simulation within the Solar Spectrum) (Tanré et al., 1992) described in detail by Zullo Júnior (1994), was used. A geometric correction was necessary to adjust the real image position. For this purpose, planialtimetric maps (scale 1:10,000), were used. In addition, points obtained in the field with the Global Positioning System (GPS) with a submetric significance were also used. In order to maintain the pixel value as close as possible to its original value, an interpolation process, called nearest neighbor method, was performed, correcting only scale distortions, displacement or rotation between the image and the terrestrial projection (Crósta, 1992). The methodology to confirm bare soil in each pixel is described in Demattê et al. (2000) and takes in consideration the evaluation of the vegetation index, color compositions and soil line concept. The pixel information was only collected and considered as bare soil, if all criteria were accepted.

\section{Statistical analysis of the spectral data}

Laboratory and orbital data were evaluated separately. For the orbital data, reflectance data of the surface layer was obtained for the following TMLandsat- 5 bands (nm): B1: 450-520, B2: 520-600, B3: 630-690, B4: 760-900, B5: 1550-1750, B7: 2080-2350. Reflectance data for a total of 227 samples was used to generate the models, while the other 227 samples were used for the validation, 20 samples were discarded because they were near the drainage site of the area. The points used to generate the models were chosen randomly, but were representative of the entire area. Laboratory spectral data acquired with the IRIS allows a higher radiometric resolution, thus allowing the establishment of a larger number of bands. The following 22 bands (B) (in $\mathrm{nm}$ ): B1: 450-481, B2: 481, B3: 481-596, B4: 596-710, B5: 710-814, B6: 814975, B7: 975-1350, B8: 1350-1417, B9: 1417, B10: 1417-1449, B11: 1449-1793, B12: 1793-1831, B13: 1865-1927, B14: 1927, B15: 1927-2102, B16: 2101-
2139, B17: 2139-2206, B18: 2206, B19: 2206-2258, B20: 2258, B21: 2258-2389, B22: 2389-2498. Besides these 22 bands, other 13 bands (or named heights) associated with specific spectral features were selected for analysis, as follows: H1: 469-532, H2: 532-768, H3: 768-876, H4: 876-1353, H5: 1353-1411, H6: 14111439, H7: 1439-1783, H8: 1860-1923, H9: 19232120, H10: 2120-2206, H11: 2206-2258, H12: 22582389, H13: 2389-2498. More details are found in Nanni \& Demattê (2001). This selection was based on empirical observations reported in the literature. An automated statistical system was then used to identify the best bands for the each model. On the 948 samples obtained from the surface and under-surface layer, 474 were randomly separated regardless of the sampling layer for generating the models and the other 474 samples were used to test the model. The data were submitted to correlation analysis using the Statistical Analysis System (SAS, 1999) software.

The soil variables used in the correlation with spectral characteristics were: organic matter content (OM), sand, silt, clay, sum of cations ( $\mathrm{SC}=\mathrm{Ca}+\mathrm{Mg}$ $+\mathrm{K})$, cation saturation $(\mathrm{V} \%=[\mathrm{SC} / \mathrm{CEC}] * 100)$, aluminum saturation $(\mathrm{m} \%)$ and CEC. Initially, predictive variables for laboratory and orbital data were selected using the SAS program. This procedure was used to determine which variables from the 22 bands (B) and 13 highest $(\mathrm{H})$, presented the highest or lowest potential for the development of the models. Afterwards, a co-linearity test of the variables was performed to prevent the overlapping of two or more variables. Multiple linear regression equations were then developed for each soil attribute. After that, these equations were tested with the reflectance data of the remaining 50\% of the samples not used to build the models. Thus, it was possible to produce a database with soil attribute values determined in the laboratory by traditional methods (DV) and values estimated by radiometry (EV). DV and EV were compared by different means allowing a more careful analysis, such the use of the Tukey test $(p<0.05)$ between mean DV and EV for each attribute obtained from laboratory and orbital radiometric data.

\section{RESULTS AND DISCUSSION}

\section{Estimate of soil attributes based on the spectral response obtained with the laboratory sensor}

Multiple linear regression equations were generated for each of the eight soil attributes using half of the data of the study area regardless of the selected layer $(0-20$ or $80-100 \mathrm{~cm})$. A total of 35 laboratory spectroradiometric variables showed that $\mathrm{m} \%$ had 13 of these variables in the regression - the largest 
number among the regressions (Table 1). The equation with the smallest number of such laboratory spectroradiometric variables (four variables) was that obtained for CEC. The key bands for the estimation of each attribute were determined statistically. The multiple analysis technique allowed the definition of the bands that best correlated with each attribute, in agreement with the findings of Huete \& Escadafal (1991) and Nanni (2000). Clay and sand had high correlation coefficients, $\mathrm{r}^{2}>0.8$ (Table 1), in agreement with Demattê \& Garcia (1999), who obtained an $\mathrm{R}^{2}$ of 0.8 for clay and with Nanni \& Demattê (2001), who found an $\mathrm{R}^{2}$ of 0.91 for clay and of 0.74 for sand. In contrast, Coleman et al. (1991) had considered a 0.63 coefficient as high for clay. The $\mathrm{R}^{2}$ values of silt were 0.56 , a result considered satisfactory. The $\mathrm{R}^{2}$ values higher than 0.75 for silt determined by Demattê \& Garcia (1999), while Nanni \& Demattê (2001) had determined a low value $\mathrm{R}^{2}=0.27$. It should be noted that among sand, silt and clay the estimation of two attributes would be sufficient since the third can be calculated by subtraction as made in traditional analyses.

The results were unsatisfactory for OM, which showed a low coefficient of determination, 0.298 (Table 1), in agreement with Demattê \& Garcia (1999), also observed by Ben-Dor \& Banin (1995b), for which $\mathrm{OM}$ had a 0.5 of $\mathrm{R}^{2}$. These authors also mentioned that greater attention should be paid to the prediction of this attribute in terms of its type. For the chemical attributes, $\mathrm{V} \%, \mathrm{~m} \%$ and $\mathrm{CEC}$, the coefficients of determination were lower than 0.6 and for the SC and $\mathrm{m} \%$ the coefficients of determination were higher than 0.6 (Table 1) .Different results were obtained, with an $\mathrm{R}^{2}$ of 0.87 for $\mathrm{SC}$ and an $\mathrm{R}^{2}$ lower than 0.32 for $\mathrm{m} \%$ by Nanni \& Demattê (2001). Coefficients of determination close to 0.50 were determined for CEC and V\% (Table 1). The result was different from those reported by Nanni \& Demattê (2001), who obtained a high coefficient for CEC (0.90).

In order to validate the use of the equations generated in the present study for the prediction of soil attributes, half of the samples were not used in the generation of the models (474 samples). The $t$-test was used as a preliminary result since this test employs the mean of a given attribute, i.e., two sets of data might present punctually different elements but statistically similar means (SAS, 1999).

There is greater potential for estimating physical parameters such as sand and clay than for chemical parameters such as $\mathrm{V} \%$. The equations for these attributes probably generated doubtful results and, thus, their use should be avoided. In the case of some attributes, DV and EV were also correlated (Figure 1). The highest coefficients of determination $\left(\mathrm{R}^{2}\right)$ were observed for sand (0.84) and clay (0.83). Silt presented low values. However, in practice, silt can be determined by subtraction since sand and clay were adequately estimated, as done in the laboratory according to Raij et al. (1987). $\mathrm{R}^{2}$ values of 0.56 for clay and of 0.51 for organic matter were determined by Ben-Dor \& Banin (1995a), with the latter value being higher than that obtained in the present study (0.41) (Figure 1).

Table 1 - Multiple regression equation models using laboratory spectral data on the estimative of soil attributes.

\begin{tabular}{|c|c|c|}
\hline Soil Attribute & Multiple Equation Model ${ }^{(a)}$ & $\mathrm{R}^{2(\mathrm{~b})}$ \\
\hline Sand & $\begin{array}{l}409.59806+(-3346.58558 * \mathrm{H} 3)+(20887 * \mathrm{~B} 11)+(-14543 * \mathrm{~B} 16)+(-10890 * \mathrm{H} 7)+ \\
(-824.77554 * \mathrm{~B} 19)+(-19212 * \mathrm{~B} 10)+(13431 * \mathrm{H} 12)+(26675 * \mathrm{~B} 21)+(-3035.10462 * \mathrm{~B} 7)\end{array}$ & 0.8174 \\
\hline Silt & $\begin{array}{l}129.83933+(1943.40654 * \mathrm{H} 10)+(2624.05031 * \mathrm{H} 9)+(1916.57891 * \mathrm{H} 8)+(2353.36975 * \mathrm{H} 5)+ \\
(2162.49950 * \mathrm{H} 1)\end{array}$ & 0.5672 \\
\hline Clay & $\begin{array}{l}376.23728+(4092.67466 * \mathrm{H} 3)+(10972 * \mathrm{H} 7)+(1409.95843 * \mathrm{H} 2)+(-25070 * \mathrm{~B} 11)+ \\
(23006 * \mathrm{~B} 16)+(23085 * \mathrm{H} 11)+(30702 * \mathrm{~B} 10)+(19095 * \mathrm{~B} 17)+(8651.36527 * \mathrm{H} 12)+ \\
(2273.14097 * \mathrm{H} 1)+(-4697.25743 * \mathrm{~B} 15)+(-6041.71261 * \mathrm{~B} 8)\end{array}$ & 0.8570 \\
\hline $\mathrm{OM}^{(\mathrm{c})}$ & $\begin{array}{l}29.00804+(-141.76148 * \mathrm{H} 2)+(-225.82107 * \mathrm{H} 3)+(-517.81987 * \mathrm{H} 13)+(746.61657 * \mathrm{~B} 1) \\
+(476.15447 * \mathrm{~B} 3)+(332.27114 * \mathrm{H} 5)\end{array}$ & 0.2988 \\
\hline $\mathrm{SC}^{(\mathrm{d})}$ & $\begin{array}{l}455.20858+(25577 * \mathrm{H} 11)+(23797 * \mathrm{H} 12)+(3138.20686 * \mathrm{H} 3)+(5295.62046 * \mathrm{H} 1)+ \\
(7983.39289 * \mathrm{H} 5)+(4108.62012 * \mathrm{H} 8)\end{array}$ & 0.6345 \\
\hline $\mathrm{V}^{(\mathrm{e})}$ & $\begin{array}{l}79.81023+(1016.67292 * \mathrm{~B} 1)+(2892.46819 * \mathrm{~B} 8)+(2560.16606 * \mathrm{~B} 7)+(1067.64273 * \mathrm{H} 4)+ \\
(3300.62458 * \mathrm{H} 12)+(-919.36419 * \mathrm{H} 10)+(488.23896 * \mathrm{H} 3)+(-1480.00508 * \mathrm{H} 11)\end{array}$ & 0.5055 \\
\hline $\mathrm{m}^{(\mathrm{f})}$ & $\begin{array}{l}-22.14932+(3801.42681 * \mathrm{H} 5)+(2050.46588 * \mathrm{H} 8)+(2082.39681 * \mathrm{~B} 1)+(6728.15162 * \mathrm{~B} 3)+ \\
(4326.51343 * \mathrm{~B} 10)+(699.51724 * \mathrm{H} 3)+(6123.58955 * \mathrm{~B} 2)+(1570.79618 * \mathrm{H} 13)+ \\
(3540.68221 * \mathrm{H} 1)+(960.41493 * \mathrm{H} 2)+(-995.46185 * \mathrm{H} 12)+(1273.60350 * \mathrm{~B} 11)+ \\
(2584.29549 * \mathrm{~B} 9)\end{array}$ & 0.6802 \\
\hline $\mathrm{CEC}^{(\mathrm{g})}$ & $753.20475+(-32058 * \mathrm{H} 11)+(26746 * \mathrm{H} 12)+(-4921.96650 * \mathrm{H} 3)+(5686.79082 * \mathrm{H} 1)$ & 0.5358 \\
\hline
\end{tabular}

(a)B1....B22; H1...H13. bands and selected heights; ${ }^{(b)}$ Significant to $0.05 \%$ and $0.01 \%$ of probability, ${ }^{(\mathrm{c})}$ Organic Matter; ${ }^{(\mathrm{d})}$ Sum of Cations;

${ }^{(\mathrm{e})}$ Base saturation; ${ }^{(\mathrm{f})}$ Aluminum saturation; ${ }^{(\mathrm{g})}$ Cation exchange capacity. 

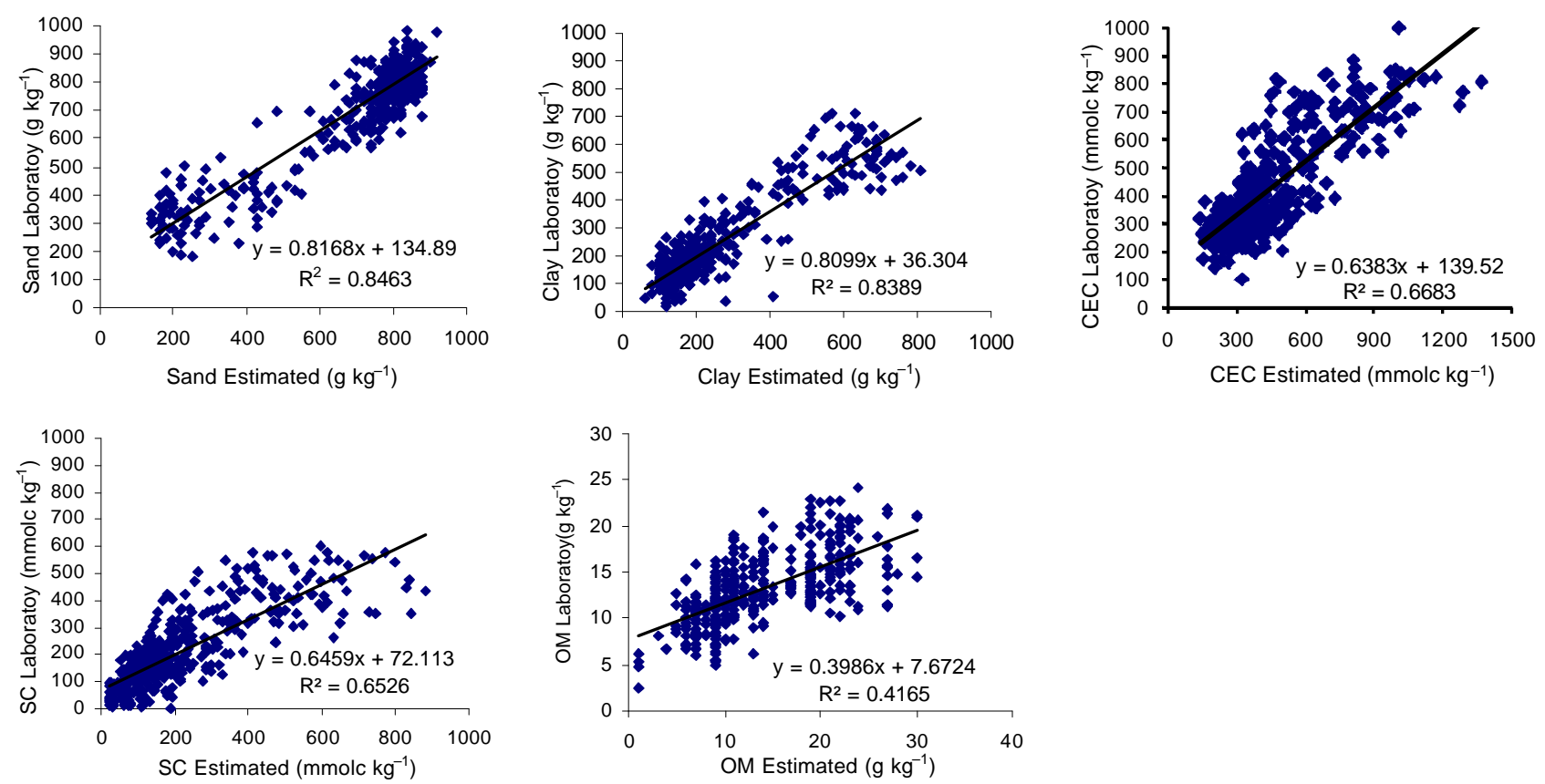

Figure 1 - Correlation between measured values from laboratory traditional analysis. DV (Y) and estimated values from laboratory spectral analysis, EV (X).

The coefficients of determination used for SC and CEC were higher than the 0.64 value reported by Ben-Dor \& Banin (1995a) for CEC. A similar model used by Ben-Dor \& Banin (1995 a, b) was the nearinfrared analysis. This model is also empirical and has been tested by various authors (Ben-Dor et al., 1997; Malley et al., 1999) for the assessment of OM and nutrients, respectively. According to this method, the number of bands for the estimation of a soil attribute can range from 25 to 63 . For example, the estimation of clay required 63 bands when using this method, while in the present study 12 bands were sufficient (Table 1). The smaller the number of factors involved in the estimation of an attribute, the easier they are to be applied and the lower the risk of overlapping band effects (Ben-Dor, 2002).

The similar EV and DV values indicated good results for the proposed methodology, mainly for sand and clay, here due to various factors: use of a sensor with high spectral resolution, a high signal-to-noise ratio, readings obtained in a constant and controlled environment, and detailed analysis of the soils in the study area. Under these conditions, the sensor detects effects of soil attributes that absorb radiant energy at discrete energy levels. However, divergent results have been noticed between several studies. The expressive values for the quantification of OM $\left(\mathrm{R}^{2}=0.79\right)$ obtained by Nanni \& Demattê (2001), is above the value determined in the present study $\left(\mathrm{R}^{2}=0.29\right)$, as the low correlation for OM (0.45), reported by (Demattê \& Garcia (1999). The lack of uniformity in the methods used by different researchers impairs the interpretation of such results.

For clay, a $\mathrm{R}^{2}$ of 0.63 was observed by Coleman et al. (1991), while Demattê \& Garcia (1999) obtained values above 0.75 for this attribute. Nanni \& Demattê (2001) reported a $\mathrm{R}^{2}$ of 0.91 for clay, while a value of 0.86 was obtained in the present study (Table 1). These divergent results can be explained by differences in the methods employed in the various studies. In addition to the use of different equipment, the main divergence lies in the determination of the bands used to develop the models and in the data of the analyzed soils.

Coleman et al. (1991) utilized eight bands, three in the visible domain, two in the near-infrared domain, two in the medium infrared domain, and one in the thermal infrared. Demattê \& Garcia (1999) used slightly different bands. In a previous study, Nanni (2000) employed a larger number of spectral bands and soil samples with highly contrasting characteristics (soils developed from basalt, shale and sandstone), leading to better correlations. These results indicate that the models are strongly influenced by the number of bands and the selected wavelength. In addition, the models are regional and should be treated accordingly, in agreement with Coleman et al. (1991).

The estimation of chemical soil attributes, such as the sum of $\mathrm{Ca}, \mathrm{Mg}$ and $\mathrm{K}$ cations, was possible in the study of Demattê \& Garcia (1999) who obtained an $\mathrm{R}^{2}$ of 0.71 . A coefficient of 0.87 was determined by Nanni (2000), while in the present study this value 
was 0.63 (Table 1). However, even laboratory chemical analyses demonstrate that methodologies are regional as described by the Council on Soil Testing and Plant Analysis (1980). These findings should stimulate a discussion about methodologies.

\section{Estimate of soil attributes based on the spectral response obtained by orbital sensor}

A multiple linear regression equation was generated for each attribute using half the samples obtained from the $0-20 \mathrm{~cm}$ surface depth, with a total of 227 (Table 2). From the six TM bands (TM 1, 2, 3, 4, 5 and 7), three (3, 5 and 7) were selected in the statistical process for the sand and silt attributes. For clay, band 2 instead of band 3 was used (Table 2). The multiple regression equations for the same attributes also using three of the initial six variables, but selecting different bands (sand - 2, 3 and 7; silt - 1, 4 and 7; clay $-1,3$ and 4) were developed by Coleman et al. (1993). According to these authors, the highest coefficient of determination was 0.4 for clay and the lowest was 0.17 for sand and silt. The values determined in the present study were $0.63,0.61$ and 0.54 for sand, clay and silt, respectively (Table 2). An $\mathrm{R}^{2}$ of 0.52 for sand using bands 1,5 and 7 , and of 0.67 for clay using bands 1 , 3, 4, 5 and 7 was reported by Nanni (2000). The equations obtained for $\mathrm{SC}, \mathrm{CEC}$ and $\mathrm{V} \%$ were those with the smallest number of TM spectral variables: only band 7 for SC and CEC and band 1 for V\%. The attributes that presented two variables were $\mathrm{OM}$ and $\mathrm{m} \%$, which also showed low coefficients of determination $(<0.46)$ (Table 2), in agreement with the values reported by Nanni \& Demattê (2001) who concluded that these equations are prone to estimation errors.

The quantification of soil attributes was tried by Coleman et al. (1993) from sensors installed on orbital platforms. They reported significant, although not consistent, $\mathrm{R}^{2}$ values ranging from 0.1 to 0.4 for sand, silt, clay, iron and OM. Their conclusion about the potential of this method motivated new studies. The results obtained in the present study confirmed those of Coleman et al. (1993) and the potential of this method since the $\mathrm{R}^{2}$ results were high especially for sand and clay (Table 2).

In order to confirm the above assumption, the equations generated with half of the samples obtained from the surface layer were tested using the soil samples that were not used in the model. A difference between DV and EV was only observed for $\mathrm{V} \%$ and $\mathrm{m} \%$. In addition, the significant mean values of DV and EV were very similar. Correlation analysis between DV and EV was also carried out with the orbital data (Figure 2).

The highest $\mathrm{R}^{2}$ were obtained for sand $(0.72)$ and clay (0.71). An $0.56 \mathrm{R}^{2}$ for clay and 0.51 for $\mathrm{OM}$ determined by Ben-Dor \& Banin (1995a), with the latter values being much lower in the present study $(0.35)$ (Figure 2). The coefficients obtained for SC and CEC were lower than the 0.64 values reported for CEC by Ben-Dor \& Banin (1995a). The coefficients of 0.52 and 0.67 respectively for the same attributes were determined by Nanni \&Demattê (2001). Similar results were observed in the present study with values in the order of 0.6 (Table 2).

The results obtained with the orbital sensor were less consistent than those obtained with the spectroradiometric laboratory sensor, in agreement with the findings of Coleman et al. (1991, 1993). This was due to the fact that the laboratory data was acquired in an environment of controlled geometry and illumination without atmospheric interference, while image data from the orbital sensor is subject to many factors which can cause interference such as soil roughness, spectral and spatial resolution, low signalto-noise ratio, atmospheric interference, and variations in the observation and illumination angles (Ben-Dor, 2002). Nevertheless, the results suggest that further

Table 2 - Multiple regression equation models using satellite spectral data on the estimative of soil attributes from the study area.

\begin{tabular}{llr}
\hline Soil Attribute & \multicolumn{1}{c}{ Satellite Multiple Spectral Equation on Model ${ }^{(\mathrm{a})}$} & $\mathrm{R}^{2(\mathrm{~b})}$ \\
\hline Sand & $128.57173+(-14.26920 * \mathrm{TM} 3)+(13.13981 * \mathrm{TM} 5)+(26.11687 * \mathrm{TM} 7)$ & 0.6356 \\
Silt & $205.73234+(4.47412 * \mathrm{TM} 3)+(-2.51728 * \mathrm{TM} 5)+(-8.37651 * \mathrm{TM} 7)$ & 0.5435 \\
Clay & $699.99540+(-13.44352 * \mathrm{TM} 7)+(-12.69294 * \mathrm{TM} 5)+(13.03814 * \mathrm{TM} 2)$ & 0.6140 \\
$\mathrm{OM}^{(\mathrm{c})}$ & $32.93323+(1.03425 * \mathrm{TM} 1)+(-1.21937 * \mathrm{TM} 7)$ & 0.4100 \\
$\mathrm{SC}^{(\mathrm{d})}$ & $794.50072+(-31.18313 * \mathrm{TM} 7)$ & 0.3466 \\
$\mathrm{~V}^{(\mathrm{e})}$ & $58.97640+\left(-2.19535^{*} \mathrm{TM} 1\right)$ & 0.0130 \\
$\mathrm{~m}^{(\mathrm{f})}$ & $-9.25324+\left(0.69115^{*} \mathrm{TM} 4\right)+(0.27464 * \mathrm{TM} 7)$ & 0.1374 \\
$\mathrm{CEC}^{(\mathrm{g})}$ & $1348.94022+(-50.85760 * \mathrm{TM})$ & 0.4595 \\
\hline
\end{tabular}

(a)TM1, TM2, TM3, TM4, TM5 e TM7, bands and selected heights; (b) Significant to $0.05 \%$ and $0.01 \%$ de probability; ${ }^{\left({ }^{c}\right)}$ Organic Matter; ${ }^{(\mathrm{d})}$ Sum of Cations; ${ }^{(\mathrm{e})}$ Base saturation; ${ }^{(\mathrm{f})}$ Aluminum saturation; ${ }^{(\mathrm{g})}$ Cation exchange capacity. 

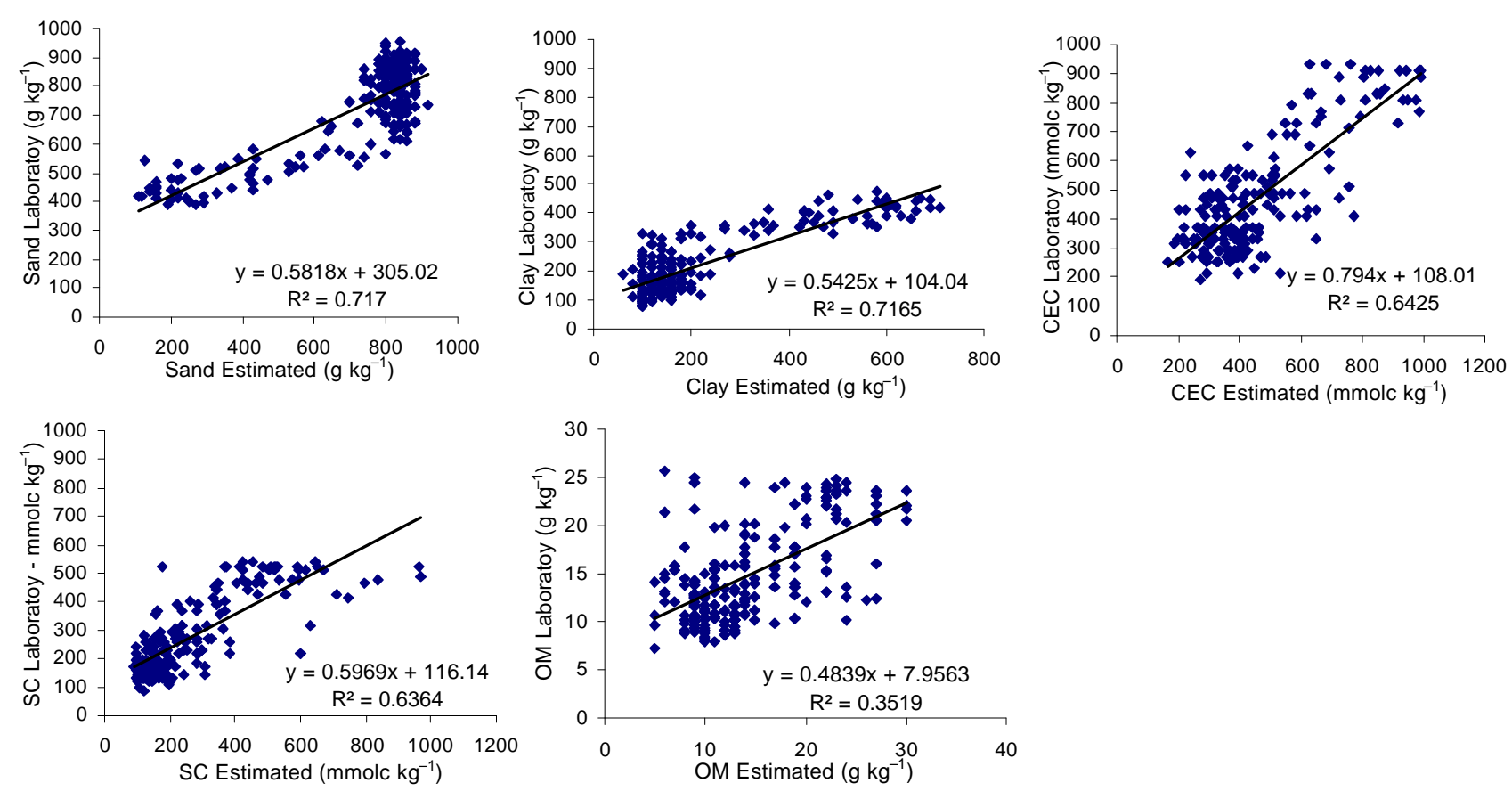

Figure 2 - Correlation between measured values from laboratory traditional analysis, DV (Y) and estimated values from orbital spectral analysis, EV (X).

studies to determine elements should be carried out, as also emphasized by Coleman et al. (1991) and BenDor (2002).

The importance of such an experiment was to prove that traditional soil analysis can be optimized by spectral information for several attributes. The appropriate methodology (laboratory or orbital) should be used according to the specific objective and in consideration of its limitations.

\section{CONCLUSIONS}

It is possible to determine soil attributes such as clay and sand content and CEC based on reflected electromagnetic energy data obtained with a spectroradiometric laboratory sensor, as shown by the close relationship between soil attribute values estimated by equations (obtained from spectral data) and those determined by routine laboratory analysis.

The use of multiple linear regression equation models determined with spectroradiometric laboratory data for estimation of soil attributes was found to be efficient when compared with a traditional method of soil extraction. Chemical parameters such as aluminum saturation and sum of cations provided significant equations with an $\mathrm{R}^{2}$ of 0.68 and 0.63 , respectively.

Laboratory spectral data was more effective when compared with orbital data. This was due to better spectral resolution at laboratory and atmospheric interference on orbital data.

\section{ACKNOWLEDGEMENTS}

FAPESP for the acquisition of the spectroradiometer IRIS, (grant 95/6259-6), for the PhD scholarship of the first author (grant 99/043252) and $\mathrm{CNPq}$ for the second author's scholarship (grant 300371/96-9).

\section{REFERENCES}

BAUMGARDNER, M.F., SILVA, L.F.; BIEHL, L.L.; STONER, E.R. Reflectance properties of soils. Advances in Agronomy, v.38, p.1-44, 1985.

BEN-DOR, E. Quantitative remote sensing of soil properties. Advances in Agronomy, v.75, p.173-243, 2002.

BEN-DOR, E.; BANIN, A. Near-Infrared analysis as a rapid method to simultaneously evaluate several soil properties. Soil Science Society of America Journal, v.59, p.364-372, 1995 a.

BEN-DOR, E.; BANIN, A. Near-Infrared analysis as a simultaneously method to evaluate spectral featureless constituents in soils. Soil Science, v.59, p.259-269,1995b.

BEN-DOR, E.; INBAR, Y.; CHEN, Y. The reflectance spectra of organic matter in the visible near infrared and short wave infrared region (400-2500 nm) during a control decomposition process. Remote Sensing of Environment, v.61, p.1-15, 1997.

CAMARGO, M.N., KLANT, E.; KAUFFMAN, J. H. Classificação de solos usada em levantamentos pedológicos no Brasil. Boletim Informativo da Sociedade Brasileira de Ciência do Solo, v.12, p.11-13, 1987.

CAMPOS, R.C.; DEMATTE, J.A.M.; QUARTAROLI, C.F. Determinação indireta do teor de hematita no solo a partir de dados de clorimetria e radiometria. Pesquisa Agropecuária Brasileira, v.38, p.521-528, 2003.

COLEMAN, T.L.; AGBU, P.A.; MONTGOMERY, O.; GAO, L.T.; PRASAD, S. Spectral band selection for quantifying selected properties in highly weathered soils. Soil Science, v.151, p.355$361,1991$. 
COLEMAN, T.L.; AGBU, P.A.; MONTGOMERY, O.L. Spectral differentiation of soils and soil properties: is it possible from space plataforms?. Soil Science, v.155, p.283-293, 1993.

COUNCIL ON SOIL TESTING AND PLANT ANALYSIS. Handbook on reference methods for soil testing. Athens: Council on Soil Testing and Plant Analysis, 1980. 130p.

CRÓSTA, A.P. Processamento digital de imagens de sensoriamento remoto. Campinas: UNICAMP, 1992. 170p.

DEMATTÊ, J.A.M.; GARCIA, G.J. Alteration of soil properties through a weathering sequence as evaluated by spectral reflectance. Soil Science Society of America Journal, v.63, p.327-342, 1999.

DEMATTÊ, J.A.M. O pedólogo e agricultura de precisão. Boletim Informativo da Sociedade Brasileira de Ciência do Solo, v.26, p.17-19, 2001.

DEMATTÊ, J.A.M.; HUETE, A.R.; FERREIRA JR., L.G.; ALVES, M.C.; NANNI, M.R.; CERRI. C.E.P. Evaluation of tropical soils through ground and orbital sensors. 35-42p. In: INTERNATIONAL. CONFERENCE OF GEOSPATIAL INFORMATION IN AGRICULTURE AND FORESTRY, 2., Lake Buena Vista, 2000. Proceedings. Lake Buena Vista: Erim, 2000. v.2. p.34-41.

EMBRAPA. Centro Nacional de Pesquisa de Solos. Sistema brasileiro de classificação de solos. Brasília: Embrapa Produção de Informação, 1999. 412 p.

GALVÃO, L.S.; VITORELLO, I.; FORMAGGIO, A.R. Relationships of spectral reflectance and color among surface and under-surface layers of tropical soil profíles. Remote Sensing of Environment, v.61, p.24-33, 1997.

GEOPHYSICAL ENVIRONMENTAL RESEARCH. Mark V dual field of view IRIS manual: version 1.3. New York: Milbook, 1996. 63p.

HENDERSON, T.L.; BAUMGARDNER, M.F.; FRANZMEIER, D.P.; STOTT, D.E.; COSTER, D.C. High dimensional reflectance analysis of organic matter. Soil Science Society of America Journal, v.56, p.865-872, 1992.

HUETE, A.R.; ESCADAFAL, R. Assessment of biophisical soil properties through spectral decomposition techniques. Remote Sensing of Environment, v.35, p.149-159, 1991.

INPE. Tutorial Spring: Spring básico. São José dos Campos: INPE, 1999. Available at: http//www.inpe.br. Accessed 25 Sept. 2002.

IPT. Divisão de Minas e Geologia Aplicada. Mapa geológico do Estado de São Paulo. São Paulo: IPT, 1981. Escala 1: 1.000.000.

LABSPHERE REFLECTANCE CALIBRATION LABORATORY. Spectral reflectance target calibrated from $0.25-2.5 \mathrm{~mm}$ reported in $\mathbf{0 . 0 5 0} \mathbf{~ m m}$ intervals. Sutton: Labsphere, 1996. $5 \mathrm{p}$.

LEMOS, R.C.; SANTOS, R.D. Manual de descrição e coleta de solo no campo. 3ed. Campinas: Sociedade Brasileira de Ciência do Solo, 1996. 84p.
MALLEY, D.F.; YESMIN, L.; WRAY, D.; EDWARDS, S. Applications of near-infra-red spectroscopy in analysis of soil mineral nutrients. Communications in Soil Science and Plant Analysis, v.30, p.999-1012, 1999.

MORRA, M.J.; HALL, M.H.; FREEBORN, L.L. Carbon and nitrogen analysis of soil fractions using near-infrared reflectance spectroscopy. Soil Science Society of America Journal, v.55, p.288-291, 1991.

NANNI, M.R. Dados radiométricos obtidos em laboratório e no nível orbital na caracterização e mapeamento de solos. Piracicaba: USP/ESALQ, 2000. 366p. (Doutorado).

NANNI, M.R.; DEMATTE, J.A.M. Is it possible estimate physicalchemical soil attributes by using laboratory and orbital sensors. In: INTERNATIONAL CONFERENCE OF GEOSPATIAL INFORMATION IN AGRICULTURE AND FORESTRY, 3., Denver, 2001. Proceedings. Denver: Veridian, 2001. CDROM

ODEH, I.O.A.; MacBRATNEY, A.B. Using AVHRR images for spatial prediction of clay content in the lower Namoi Valley of Eastern Australia. Geoderma, v.97, p.237-254, 2000.

POST, D.F.; HORVATR, E.H.; LUCAS, W.M.; VVRTE, S.A.; EHASZ, M.J.; BATCFULY, A.K. Relationship between soil color and Landsat reflectance on semiarid Rangelands. Soil Science Society of America Journal, v.58, p.1809-1816, 1994.

RAIJ, B. van.; CANTARELlA, H.J.A.; FURLANI, A.M.C. Recomendações de adubação e calagem para o Estado de São Paulo. 2.ed. Campinas: IAC, 1996. 285p.

RAIJ, B. van.; QUAGGIO, J.A.; CANTARELLA, H.; FERREIRA, M.E.; LOPES, A.S.; BATAGLIA, C.O. Análise química do solo para fins de fertilidade. Campinas: Fundação Cargill, 1987. $170 \mathrm{p}$.

SAS INSTITUTE. Software user's guide: version 8.2. Cary: SAS Institute, 1999. 291p.

SENTELHAS, P.C., MARIN, F.R.; PEREIRA, R.; ANGELOCCI, L.R.; VILA NOVA, N.A.; BARBIERI, V. Análise de dados climáticos e do balanço hídrico climatológico de Piracicaba (1917-1997). Piracicaba: USP/ESALQ, 1998. 81p.

TANRÉ, D., HOLBEN, B.N.; KAUFMAN, Y.J. Atmospherie correction algorithm for NOAA-AVHRR products: theory and application. Transactions Geoscience Remote Sensing, v.30, p.231-248, 1992.

USDA. Soil Survey Staff. Keys to soil taxonomy. 8ed. Washington, D.C.: USDA-NRCS-NSSC, 1998. 422p.

ZULlO JÚNIOR, J. Correção atmosférica de imagens de satélite e aplicações. Campinas: UNICAMP, 1994. 191p. (Doutorado).

$\overline{\text { Received March }}$ 29, 2007

Accepted August 29, 2008 